\title{
Dvojjediná osobnost Jána Zambora (básník a znalec poezie)
}

\author{
Ivo Pospíšil (Brno)
}

Ján Zambor: Samo Bohdan Hroboň - Prosbopej slovenského chorlavca žobráka. V interpretácii Jána Zambora. Bratislava: Literárne informačné centrum, 2020. 153 s. ISBN 978-80-8119-134-3.

Ján Zambor: Brána. Kordîky: Skalná ruža, 2020. 101 s. ISBN 978-80-89815-34-7.

Jan Zambor: Čem ja k vam približus’. Moskva: „MIK“, 2017. 159 s. ISBN 978-5-87902-366-4.

Představovat Jána Zambora (roč. 1947) na Slovensku je v podstatě nadbytečné a do značné míry se to týká i českého prostředí, nebot i zde je Zambor znám jako originální básník i překladatel, zejména z ruštiny a španělštiny. Básnické sbírky Zelený večer (1977), Neodkladné (1980) až po Soprán daždouých kvapiek (2000), když nepočí- j táme řadu výborů, udělaly básníkovi jméno v zahraničí a překladatel byl sám překládán do řady jazyků. Zambor patř́ k těm štastlivcům, kteří se na literaturu dívají ze dvou zorných úhlů, a on dokonce ze tří nebo čtyř: jako literární historik a teoretik, překladatel básní: známá je jeho monografie o Kraskovi a české moderně a Miroslavu Válkovi; práce o poezii Báseñ a ticho (1997), Preklad ako umenie (2000), Interpretace a poetika (2005), Tvarovanie básne, tvarovanie zmyslu (2010) se staly př́iznačným projevem spojení literární teorie a praxe. Stěžejní prací je jeho Stavebnost' básne. ${ }^{2}$ Vícekrát jsme už o něm psali, také na stránkách Slavica litteraria, mimo jiné o jeho knize Preklad ako umenie (2000), Kniha ruskej poézie (2011), Niečo ako láska, niečo ako sol'. Miroslav j Válek v interpretáciách (2013), Dom neviditelných (2014) nebo Vzlyky nahej duše. Ivan Krasko v interpretáciách $(2016)^{3}$. Zambor je sice teoretik, ale

1 Tento výstup vznikl na Masarykově univerzitě v rámci projektu Mezislovanské kulturni a literárni vazby číslo MUNI/A/1331/2020 podpořeného z prostředků účelové podpory na specifický vysokoškolský výzkum, kterou poskytlo MŠMT v roce 2021.

2 ZAMBOR, Ján: Stavebnost' básne. Bratislava: Literárne informačné centrum, 2018.

3 ZAMBOR, Ján: Niečo ako láska, niečo ako sol. Miroslav Válek v interpretáciach. Bratislava: Literárne informačné centrum, 2013. Týž: Vzlyky nahej duše. Ivan Krasko v in- více mu sedí role interpreta, nebot jako člověk, který poezii rozumí také a hlavně zevnitř, dokáže vyložit autorovu motivaci a významotvornou funkci básně, přičemž právě z takových interpretací konstruuje pak celistvý portrét básnického typu jako v př́ípadě Válka nebo Kraska, stejně jako překladatelský transfer z jednoho prostředí do druhého. Své hodnocení - v podstatě vždy kladné, byt s komentáři a poznámkami, jsem vtělil, do řady recenzí.

Před časem jsem přemýšlel o charakteru Zamborovy tvorby, např. ve srovnání s českým kompozitologem Františkem Všetičkou, který je také básníkem a prozaikem, zabývá se těmito dvěma sférami vyrovnaněji než Zambor, který je přece jen orientován více na poezii, také překládá, vymýšlí metodologii a terminologii literární struktury, poetiky. Společné je jejich pnutí k formalistům a strukturalistům, možná je tu Všetička ortodoxnější, jaksi stabilnější tam, kde je Zambor flexibilnější; Všetička navíc hledá prostorové koordináty slovesných tvůrců, jde po jejich životních stopách, ał už v Polsku, na Moravě nebo ve Vídni. Řekl bych, že oba zaujímají ve svých literárních prostředích klíčovou pozici, svým způsobem momentálně nenahraditelnou. To je i dnes pozice zcela výjimečná.

Psal jsem dosud o Zamborovi poměrně mnoho, většinou zcela kladně, někdy mírně polemicky jako v případě Válkově. ${ }^{4} \mathrm{U}$ recenzovaných

terpretáciách. Bratislava: Literárne informačné centrum, 2016.

4 POSPÍŠIL, Ivo: Poezie a politika: básnik mezi konjunkturalismem, sebeobětovánim, ostrakizaci a osamèlostí. In: Česká a slovenská poezie: Slovo a mlčení. Eds. Ivo Po- 
publikací na hraně vědy a umění jde jednoznačně o vysoce přínosné věci. Zejména první edice skvělé a žel pozapomenuté básně Hroboňovy zaujme na první pohled propracovanou analýzou, pečlivou textologickou prací a také kolektivním pojetím tohoto vydání, $\mathrm{k}$ němuž přispěli editorka slovenských básnířek Andrea Bokníková a překladatel úryvku básně John Minahane (jeho př́ijmení je starobylé a má místní irský původ a různé varianty ${ }^{5}$ ) - ten žije od 1996 na Slovensku a překládá do angličtiny slovenskou literaturu, mj. Margitu Figuli (Tri gaštanové kone), Ladislava Novomeského, Milana Rúfuse, Jána Buzássyho, Milu Haugovou, Ivana Štrpku; mezi jinými přeložil Hviezdoslavovy Krvavé sonety (Bloody Sonnets, vyšlo 2018). Plodem tohoto úsilí je brilantní edice a studie, silně versologická a současně objevující v návaznosti na minulé slovenské edice iniciační, originální tvorbu Sama Bohdana Hroboně (1820 Liptovská Sielnica - 1894 tamtéž). Zambor formulačně propojuje životní osudy Hroboňovy, v podstatě tragické, s jeho básnickou tvorbou, jež ho řadí $\mathrm{k}$ vlivnému proudu světové literatury už tím, že pokračuje v žánrové a poetologické tradici „plačů“, stížností, žalob, zoufalců a pohřebních písní: jako takového zoufalce s obrovským intelektuálním potenciálem ukazuje Hroboně i román Vladimíra Macury Informátor. ${ }^{6}$ Zambor analyzuje báseň Prosbopej slovenského chorlavca žobráka $\mathrm{z}$ různých zorných úhlů, mezi jinými z hlediska existenciálního, duchovního, ale také z pozice litanické modlitby, písňově hudebního textu; po-

spíšil - Anna Zelenková. Brno: Česká asociace slavistů, 2015, s. 159-169; Slovenská kritika básnického prékladu (Zambor, Ján: Preklad ako umenie. Bratislava: Univerzita Komenského, 2000). Opera Slavica 11, 2001, č. 1, s. 65-67; Zázrak ruské poezie ukotvený v plynutí a intimitě: originální personálni pri̛rez ruskou poezii z pera slovenského překladatele (Zambor, Ján: Kniha ruskej poézie. Prešov: Vydavatel'stvo Michala Vaška, 2011). Slavica litteraria 15, 2012, č. 1, s. 161-164; Výjimečná syntéza (Zambor, Ján: Stavebnosṫ básne. Bratislava: Literárne informačné centrum, 2018). Proudy, 2019, č. 1. http://www.phil.muni. cz/journal/proudy/filologie/recenze/2019/1/pospisil_vyjimecna_synteza.php\#articleBegin

$5 \quad$ Viz https://en.wikipedia.org/wiki/Moynihan.

6 Viz POSPÍŠIL, Ivo: Slovenská téma v románe Vladimíra Macury Informátor. Slovenské pohlady, 2018, č. 6, s. 3440 (prel. Ingrid Skalická). dle mého názoru patří text zaplněný desítkami, snad i stovkami lexikálních neologismů (jsou, jak patrno, i v samotném názvu básně), většinou staroslověnského, obecně slovanského, a hlavně ruského původu, takže svazek musel být doprovozen speciálním slovníčkem použitých novotvarů, patří ke clusteru básnických děl, která vyjadřují zoufalství člověka, jeho touhu po změně, jeho obrácení k Bohu i jeho stížnosti Bohu a žalobu, kvílení, to vše ostatně najdeme v názvech takových básní, byt’ se ovšem lišících, někdy málo, někdy podstatně. Moje někdejší doktorandka, tehdy z Pedagogické fakulty Jihočeské univerzity, nazvala svou disertaci Dialogy zoufalců. ${ }^{7} \mathrm{Je}$ to obrovská řada, která se táhne od sumerského Gilgameše k biblickému Jóbovi, ale týká se také moderní poezie, např. renesančně barokních Trenů Jana Kochanowského, jemuž zemřela dceruška Voršilka/Urszula/Orszula, ał již šlo o fiktivní nebo skutečnou událost, sentimentalistické žaloby či stížnosti z pera Edwarda Younga, který trpěl smrtí manželky a přátel; jde o lament Stižnost aneb Nočni myšlenky/rozjimáni $o$ životě, smrti a nesmrtelnosti (The Complaint, or Night Thoughts on Life, Death, and Immortality, 1742-1745); k podobnému druhu poezie patří i beatnické Kvileni (Howl and Other "Poems“, 1956) Allena Ginsberga obžalovaného za ně z obscénnosti, i když evidentně jde hlavně o litanickou poezii a vlastní generaci, která se postupně zničila a skončila v šílenství. Napětí mezi prosbou k Bohu, jemuž je zcela důvěřováno, a protestem proti jeho nespravedlivé autoritě se jako červená nit vine světovou literaturou. Zambor nenechává nic náhodě a všeho si všímá: jak slovanské orientace, mytičnosti, mytologičnosti, mesianismu, ale také výstavby písňové a veršové, v níž ukazuje na dynamické tvarování verše, kdy se mění počet slabik a celkové rytmické vyznění je v neustálém pohybu. Ukazuje se, jak tato báseň, jakoby výtvor podivínského tvưrce, dílo, jež svým hromaděním neologismů je jen málo

7 NIKLESOVÁ, Eva: Dialogy zoufalcu: poetika a struktury. Dialogické texty o smyslu lidské existence v nejstaršich světových literaturách a v literaturách stredoevropského areálu. Brno: Masarykova univerzita, 2016. 
přístupné dnešnímu čtenáři, anticipovalo experimenty moderny, např. jazykové experimenty Chlebnikova a Kručonycha: to Zambor jako překladatel ruské poezie a sám básník zřetelně zaznamenal. A současně manifestoval, kterak Hroboň volí neologismy s prostorovým významem, jak přesahuje běžné dimenze poezie, a upozornil na miltonovský kontext jeho díla (Ztracený ráj). Snad by se tu hodilo i slovo „krajnost“ nebo „extrémnost“, jež se v této básni projevuje, jež nemůže nepřipomenout podobně alternativní, krajní ráz Štúrova německy psaného traktátu Das Slawenthum und die Welt der Zukunft.

Další částí knihy je edice této básně, edičně textologické poznámky a kontextuální Pieseñ žobráka, připojené poznámky a komentáře, následuje slovníček Hroboňových neologismů, důkladná studie Andrey Bokníkové o básníkově životě a díle a potom básnický ohlas básníka a versologa Zambora; najdeme tu skvělý do angličtiny přeložený úryvek básně a obrazovou přílohu. Summa summarum: svazek, jaký má být, moderní, důkladný, textologicky dokonalý, inspirativní a objevný.
Básnická sbírka Brána, kterou nás Zambor překvapil v roce 2020, je opět poměrně složitě strukturovaná. Kromě ohlasů různých básnických forem a básnických osobností tu najdeme záznamy každodennosti, jak to Zambor umí. První část je věnována takovéto směsi, v níž převažují životní momentky, jiskérky zážitků, druhá se rozšiřuje k společenskému gestu (Jáchymov), ale aluzivně je vše prosyceno palimpsestičností tradice (korejská veršová forma sidžo, japonské tanka a haiku, připominá se „diskrétně“ Ján Holllý, Ivan Krasko aj.). Ona reminiscentnost je plíživá, nevnucuje se, a tak je působivá.

Natalii Švedovové se podařil velmi dobrý překlad výběru ze Zambora do ruštiny, tipoval bych, že i s básníkovou pomocí nebo konzultací, nebot Zambor je nejen překladatelem ruské a španělské poezie, ale také znalcem básnické tradice a versologem a zná i možnosti poetické slovenštiny a ruštiny.

Všechny tři knihy, v nichž Ján Zambor dominuje, patří k velmi kvalitním publikačním výstupům, jimiž se literární Slovensko může chlubit a to není v dnešní hodnotově zmatené době málo.

\section{prof. PhDr. Ivo Pospíšil, DrSc.}

Ústav slavistiky

Filozofická fakulta, Masarykova univerzita

Arna Nováka 1, 60200 Brno, Česká republika

ivo.pospisi@phil.muni.cz 